Mykolaichuk M. M.

Doctor of Sciences in Public Administration, Professor,

Head of Economic and Financial Policy Chair

Odesa Regional Institute for Public Administration of

National Academy for Public Administration Under the President of Ukraine

Burdyha D. M.

Postgraduate Student of Economic and Financial Policy Chair

Odesa Regional Institute for Public Administration of

National Academy for Public Administration Under the President of Ukraine

\title{
PUBLIC-PRIVATE PARTNERSHIP AS A CONSTITUENT OF THE MECHANISM FOR PROVISION OF ENERGY EFFICIENCY OF THE HOUSING SECTOR AT THE LEVEL OF TERRITORIAL COMMUNITIES OF UKRAINE
}

\section{Summary}

The main directions of the state policy of Ukraine on energy efficiency, as well as prospects and obstacles in the processes of ensuring the effectiveness of the energy efficiency management system at different levels of government, are studied in this research. A set of measures aimed at ensuring the energy efficiency of the residential sector of Ukraine is presented, which conditionally divided into three groups according to the cost estimate.

The authors proved the suitability of using a public-private partnership $(P P P)$ as a component of the mechanism of managerial influence in the process of creation and effective functioning of the amalgamated territorial communities (ATC) and housing and communal services (HCS).

Public-private partnerships are determined as one of the components of the mechanism for improving energy efficiency in the housing sector, as the implementation of energy efficiency measures requires the use of appropriate funding and concrete actions and levers by local authorities.

Based on the analysis of international experience in the use of publicprivate partnership in the housing and communal sector of the economy, the forms of PPP implementation in Ukraine in the conditions of decentralization of power are proposed.

The advantage of using a public-private partnership in the housing sector of Ukraine is proved.

\section{Introduction}

The current financial instability and insufficiency of advanced energyefficient technologies and solutions in the energy infrastructure of Ukraine do not meet the needs of modern society. Therefore, in fact, there are no proper conditions to ensure decent requirements and high standards of quality of daily life for the residents of most of the amalgamated territorial communities. 
This situation, in turn, complicates the implementation of sustainable energy and socio-economic development projects.

The transition to sustainable development standards requires changes in the energy structure of the economy. This process also requires changes in engineering infrastructure, investment and regulatory policy and the legal basis; changes in values in the formation of consumption and stereotypes of the behaviour of end-users (companies, citizens and government agencies).

Public-private partnerships (PPPs) are a relatively new tool for stimulating economic development among developing countries. It should be emphasized that this type of collaboration between the state and business can increase the efficiency of management, attract investment, implement innovative solutions and technologies, as well as distribute business and investment risks between partners.

The implementation of energy efficiency policy in Ukraine, which is conditioned by the processes of European integration, requires a transition to a qualitatively new level. The Partnership and Cooperation Agreement between Ukraine and the EU declare that the effective functioning of the governance system must base on the principles of equality and transparency for all its participants. The housing sector is no exception. Excessive energy consumption causes high costs and risks in the areas of energy security, trade balance, economic and social activity, and environmental protection.

The course on energy efficiency indicates promising areas for innovation, expands business opportunities in the world of energy-saving and energy efficiency, stimulates demand for energy-saving products and technologies (Nejkova, 2010).

At the national level, the Resolution of the Cabinet of Ministers of Ukraine «On Approval of the Concept for the Implementation of Mechanisms for Sustainable Financing of Energy Efficient Measures (creation of the Energy Efficiency Fund)» dated July 13, 2016, No. 489-p defines and implements a mechanism for accounting, regulated and energy-saving residential buildings by applying new approaches to the implementation of state policy on financing energy efficiency measures with the involvement of international financial organizations and donors.

The works of such scientists as Zapatrina I. V., Neikova I.S., Pavliuk K. V., Delmon J., Grimsey D., Hart O., Hodge G. and others are devoted to the issue of public-private partnership in various spheres of public administration.

Energy-efficiency issues in the field of housing and communal services are considered by Maksymenko O.L., Maksymov A., Novoseltsev A.V., Hansen S.J., Bertoldi P., Langlois P., Sorrell S. and others.

In the presented study, the authors try to combine these two scientific areas to ensure the energy efficiency of the housing sector of Ukraine by involving public-private partnerships in public administration mechanisms at the level of territorial communities. 


\section{Part 1. Prerequisites for modern challenges to the public administration system in Ukraine}

The process of decentralization of power, launched in 2014, is accompanied by repeated attempts to build a new model of territorial organization of authority and administrative and territorial organization. However, most of these attempts remained at the stage of conceptual justifications or legislative initiatives. The model of financial management of decentralization under the new conditions of the organizational structure of the amalgamated territorial communities is not finalized either. Under such circumstances, in our opinion, it would be appropriate to use the opportunities of public (state) - private partnership.

The interaction of business and public authorities is an essential condition for the effective functioning of modern society. It is in the activities of the institute of public-private partnership that the nature of these relations is most clearly manifested.

According to the international practice, the essence of this phenomenon is the establishment of long-term strategic relations in the implementation of socially significant projects between the private sector and public authorities, which represents both central executive bodies and local governments (Zapatrina, 2010).

In the conditions of decentralization of power, an important task arises, which is the search for financial resources to manage the development of territorial communities, which in the new regional and spatial structure becomes especially important. As a result of the adoption of amendments to the Tax Code of Ukraine and the Budget Code of Ukraine, the financial capabilities of local self-government have been significantly expanded. Simultaneously with the expansion of the base for the formation of the revenue side of local budgets, there was a transfer of a significant amount of expenditures, primarily social, to local budget expenditures. This situation necessitates the search for ways to generate more sustainable revenues of local budgets. That is why, in Ukraine, there is a need to improve the current system of formation and distribution of local budget revenues. In this process, the public-private partnership acquires significance especially important.

Accordingly, the private partner (individual or enterprise) is responsible for implementing a project designed to address some of the socio-economic or environmental problems of the local community.

At the level of a separate territorial community, the practical application of the PPP mechanism requires that local authorities have legal, economic, social and communicative skills to initiate partnerships, select private partners, and conclude agreements with them. It is essential when the authorized body can analyse the effectiveness of the proposed project: justify the socio-economic and environmental consequences of its implementation, take into account the possible negative impact on the environment, identify prospects or problems that may arise after the contract.

When initiating a PPP project, community governing bodies must comply with the relevant requirements of domestic law. First of all, such agreements 
must conclude for five years term, which requires local authority's political independence, strategic thinking, long-term planning skills and project work. Secondly, the purpose of completing any PPP agreement should be strict and priority adherence to the interests of the community, which requires not only the experience of governing bodies but also trusting and transparent relations within the community. The community needs to understand that the transfer to a private partner of commune's objects does not presuppose the transfer of ownership of these objects or the land, which they locate on.

Third, given that the partnership provides for a clear division of risks between its participants, the local community, represented by the local government, must be aware of the joint and several liabilities for the envisaged obligations. Finally, giving a private partner the right to manage (use, operate) or acquire, or create (construction, reconstruction, modernization) a facility in the community, should provide a fair distribution of not only risks but also income (profits) among members of the community. Therefore, one of the relevant criteria for determining the feasibility of applying the PPP mechanism for the interests of the population is its ability to ensure higher efficiency compared to the independent implementation of the planned project by the community.

Government support for the implementation of the PPP project can be ensured by providing guarantees to local governments; partial financing of the project from the regional budget or payment of certain payments to a private partner; acquisition of goods or services produced by a private partner under a cooperation agreement for the needs of the territorial community (Zapatrina, 2011).

According to some scholars, a public-private partnership is relevant to ensure the development of rural areas of Ukraine. However, the transition process complicates by internal contradictions and objective circumstances. The conditions for the implementation of the public-private partnership in Ukraine should be further democratization of the governance system, completion of the process of community unification, the involvement of community representatives in the management of territories, development and implementation of local policy (Maksymov, et al., 2015).

In our opinion, a promising area for expanding the possibilities of PPP is the development of housing and communal services (HCS). In the current context of reforming the administrative and territorial system, the amalgamated territorial communities must maintain the housing and communal services located on their territory and provide the residents of the commune with the necessary assistance. The maintenance of the ATC's house and shared infrastructure must carry out with the financial participation of the community and certain subsidies from the state. At the same time, housing and communal services should not be fully subsidized, the provision of services should bring economic benefits to the housing and communal services enterprise and the community, at the same time, be affordable for consumers. 
The transfer of powers to maintain housing and communal services to the basic level of local self-government expands its possibilities for concluding PPP agreements. At the level of ATC, it is possible to use first of all traditional approaches to a public-private partnership, namely, to consider it as a way of financing and development of infrastructure projects in the field of housing. PPP can implement by combining the resources of the state and a private partner. PPP facilities must remain the property of ATC.

In our opinion, another issue, which connects with the efficiency of the PPP system in Ukraine, is the tariff policy of the natural monopoly, which is housing and communal services. One of the conditions for the effectiveness of PPP projects in the field of HCS is their long-term nature. It believes that the average payback period of investment projects in this area is $5-10$ years. The level of tariffs (prices) depends on the profit that can be obtained in the process of project implementation and, as a consequence, the payback period. Therefore, in our opinion, the risk factor is the tariff policy in housing. It is possible to reduce the investor's risk due to a stable pricing policy during the project implementation period. Frequent changes in tariffs can be considered a destabilizing factor that increases the level of uncertainty and risk regarding the expected payback period of projects.

According to experts, today, in Ukraine, there are no effective mechanisms of influence of consumers of housing and communal services on their suppliers. The procedures for selecting suppliers for consumers remain opaque, which creates distrust of performers and does not motivate the latter to improve service quality (Pavliuk K. \& Pavliuk S., 2010).

Therefore, to ensure the conditions for sustainable development of territories, the state policy on energy efficiency should be aimed at:

- uninterrupted, high-quality and safe supply of energy resources for the needs of society in conditions of both standard and unique requirements;

- economic efficiency of the energy sector of Ukraine and the functioning of energy supply systems;

- the energy efficiency of energy consumption by the national economy and in particular the housing sector;

- the ability of the state to formulate and implement a policy to protect national interests regardless of existing and potential threats of internal and external nature in the energy sector.

The effectiveness of that policy reflects through the achievement of the targets for the energy efficiency indicators system for enterprises, the region and the country (Delmon, 2009).

The main goal of implementing the state policy on energy efficiency is to increase energy security. From the population, increasing energy efficiency makes it possible to increase the level of income and reduce the cost of purchasing energy services. For society, this is a course towards sustainable development, which is expected to overcome energy poverty, increase the competitiveness of the region and the country as a whole.

One of the conditions for successful energy efficiency in the residential sector is the motivation of energy-saving consumer behaviour and the 404 
introduction of mechanisms to improve energy efficiency, taking into account the financial, organizational, technical and legal components.

At the central government level, there is considerable interest in improving the country's energy security, stabilizing the balance of payments, reducing subsidies and achieving other macroeconomic and social goals. The state has high hopes for owners of individual houses and associations of co-owners of apartment buildings (condominiums), which can implement programs to improve energy efficiency on credit with partial compensation from the state. However, the population is not confident in both their financial capabilities and state compensation and does not understand the technical side of energy efficiency measures (Novoseltsev \& Evtukhova, 2003).

Thus, the benefits of PPP can be used in the process of establishing parity of interests between the appointed state power, the elected control at the level of the amalgamated territorial communities, private business and citizens.

This partnership will be effective only if all parties - the state, ATC, private business and the consumer - receive a positive effect from the coordination of the decision. That is, the condition of optimality according to Pareto will be provided: if under the terms of any changes in the economic system, while increasing the welfare of at least one of its participants, it is not allowed to reduce the welfare of others. Cooperation is not limited to the implementation of projects and programs on a long-term basis and economic effect. It should be a systematic interaction between all stakeholders - state, local governments, local communities, private businesses and citizens.

\section{Part 2. Ways to involve public-private partnership to the mechanisms of public management of energy efficiency in the housing sector of Ukraine}

The practical experience of managing and implementing PPP projects shows that in many cases, in such a partnership, central and local governments have different interests, sometimes even conflicting ones. At the same time, the local community may have a different vision from the central authorities regarding the optimal use of the respective plots, taking into account the interests of the residents of the territory. In this case, at the stage of initiating the project, which implements in the form of PPP, local governments and central executive bodies should be involved in the negotiation process on these issues as separate entities, each of which defends its interests and has different risks.

The largest buyer of energy within its territory is the local budget, so local authorities need to reduce energy costs and ensure sustainable development of the region.

The largest consumer of thermal energy in the city is the population, so an essential task of the city council is to raise awareness of members of the local community on the implementation of energy-saving measures.

Ensuring energy efficiency of the residential sector of Ukraine requires a change in approaches to the construction and reconstruction of residential and public buildings and structures, the introduction of modern technologies and 
advanced energy-efficient equipment in the development of housing and public facilities. Measures aimed at ensuring energy efficiency of the residential sector can divide into three groups (Maksymenko, 2015).

The first group includes low-cost measures that have a small impact (5-10\%) on improving energy efficiency in residential buildings (however, a well-chosen action can lead to much more significant savings). Such measures apply in the case of process optimization, are cost-effective and have a short payback period.

The second group includes measures of average value, which have an impact in the range from $10 \%$ to $25 \%$, are cost-effective, with a payback period of three to ten years.

The third group is high-value measures (impact - up to 90\%). Large-scale actions should implement in the event of a complete renovation, construction of new facilities and systems. The implementation of energy efficiency measures requires the use of appropriate funding and concrete actions and levers by local authorities.

In Ukraine, the adoption of the Law of Ukraine «On Public-Private Partnership» in 2010 (Zakonodavstvo Ukrainy, 2010) and a package of regulations ensuring the implementation of its provisions, opens up new opportunities for attracting private investment and private initiative to improve the efficiency of services and infrastructure development.

To create an environment, in which the potential of PPP can use to the fullest, the authority intending to start a partnership must understand the real motives that incentify private entities to implement public projects and the essence of this mechanism (Pavljuk K. \& Pavljuk S., 2010).

Analysis of existing approaches to the definition of PPP shows that it is considered in two aspects: 1) as a system of economic relations (economic mechanism of cooperation) between the public and private sectors; 2) as a form of a legal contract for the performance of a specific public task (infrastructure asset management) in the way of development and implementation of a particular type of investment project.

The purpose of such cooperation is to achieve mutual benefits, and the main feature is to direct the benefits to both commercial and public tasks. A key advantage of PPPs is that maximizing the use of public sector opportunities and combining the experience of both sectors shares responsibility for a particular service, as well as the risks involved. The implementation of general tasks through the private sector is through the use of specific skills in this area. The private entity, through cooperation with other, acquires the complementary skills and knowledge necessary to implement the investment in a way that allows achieving the expected effects and allows you to maximize using the synergy of activities (Grimsey \& Lewis, 2005).

Now, PPP in Ukraine is identified as one of the critical mechanisms for implementing the policy of modernization of the national economy and solving critical socio-economic problems of the country. This situation is due to the fact that the implementation of large-scale projects in various sectors of the economy requires significant investment resources, an authoritative source 406 
of which can be a private business. At the same time, in the conditions of post-crisis development, business interest in state support is growing, which will reduce the risks of private investment, increase the reliability of investment projects for credit institutions.

In the field of investment attraction, PPP is identifying as one of the main areas of implementation of the Program for the Development of Investment and Innovation in Ukraine and national projects (Hansen, Bertoldi, Langlois, 2009).

In Ukraine, the housing sector has excellent potential for the development of public-private relations. The needs in investment resources of housing and communal services enterprises reach hundreds of billions of funds for modernization and restoration of housing stock and housing and commune infrastructure, an increase of energy efficiency of buildings, reduction of natural gas consumption by communal energy enterprises, improvement of drinking water quality.

Public (state) and private investors should pool their financial resources and efforts to improve legislation governing housing services, motivate energy-efficient behaviour, modernize and renovate homes to ensure energy efficiency in the housing sector. It is necessary to take into account not only the distribution of income from the provision of housing and communal services but also the risks associated with this activity.

This approach to solving urgent problems will ensure the attraction of private investment in the development of the housing sector, revision of tariff policy and rules for providing budget support in this area.

The attraction of the private sector in the development of the housing sector in the form of consulting services, lease, management, a concession of housing and communal services, the use of mixed types of public-private partnership, the formation of joint ventures in heat and water supply and sewerage, partnerships, aims to:

- implementation of priority projects for modernization of public utilities by attracting financial resources and installation of equipment;

- introduction of exceptional management owned by the private sector for the implementation of large integrated programs and projects in the housing and communal services sector;

- introduction of new technologies by the private sector in the housing and communal services sector;

- joint participation of the state, local governments and private partners in research, development of the legal framework, raising public awareness, etc.

For each specific project, a form of public-private partnership should be chosen to take into account the goal of attracting private business and balanced risk-sharing (Hart, 2003).

According to the central and local executive bodies in Ukraine as of January 01, 2020, 187 agreements were concluded based on PPP, 52 agreements of which were implementing (34 - concession agreements, 16 - joint venture agreements, 2 - other agreements), 135 agreements were not implementing (4 agreements - expired, 18 agreements - terminated, 113 
agreements - not fulfilled) (Ministry of Economic Development, Trade and Agriculture of Ukraine, 2020)

Table 1

Agreements concluded based on PPP, which implemented in Ukraine as of January 01, 2020 (compiled by the authors according to data from the Ministry of Economic Development, Trade and Agriculture of Ukraine)

\begin{tabular}{|c|c|c|c|c|c|c|c|c|c|}
\hline \multirow[b]{2}{*}{ Region } & \multicolumn{9}{|c|}{ Areas of conclusion of contracts } \\
\hline & 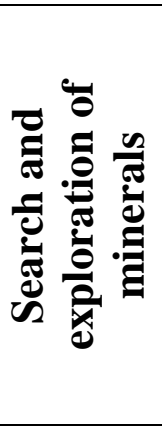 & 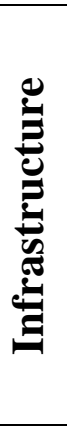 & 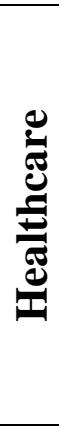 & 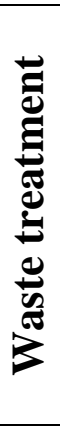 & 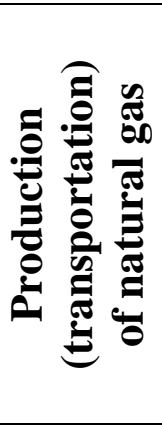 & 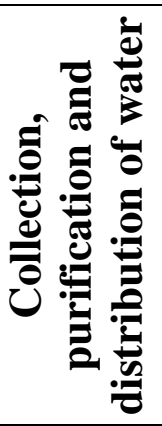 & 造 & 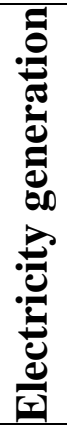 & $\stackrel{\bar{\theta}}{0}$ \\
\hline \multicolumn{10}{|l|}{ AR Crimea } \\
\hline \multicolumn{10}{|l|}{ Vinnytsia } \\
\hline \multicolumn{10}{|l|}{ Volyn } \\
\hline \multicolumn{10}{|l|}{ Dnipropetrovsk } \\
\hline Donetsk & 1 & & & 1 & 2 & & & & 1 \\
\hline Zhytomyr & & & & & 1 & & & & \\
\hline Zakarpattia & & & & & 3 & 1 & & & \\
\hline Zaporizhzhia & & & & & & 3 & & & 1 \\
\hline Ivano-Frankivsk & & 1 & & & & & & & \\
\hline Kyiv & & & 1 & & & 4 & & & 1 \\
\hline Kirovohrad & & & & & & & 1 & & \\
\hline Luhansk & & & & & & 1 & & & \\
\hline Lviv & & & 1 & & 1 & 1 & 2 & & \\
\hline Mykolaiv & & & & & & 10 & & 1 & \\
\hline Odesa & & 5 & & & & & & & 1 \\
\hline Poltava & & & & & & 1 & & & \\
\hline \multicolumn{10}{|l|}{ Rivne } \\
\hline \multicolumn{10}{|l|}{ Sumy } \\
\hline \multicolumn{10}{|l|}{ Ternopil } \\
\hline Kharkiv & & & & & & & & 1 & \\
\hline Kherson & & 1 & & & & & & 1 & \\
\hline Khmelnytskyi & & & & & & & & & 2 \\
\hline \multicolumn{10}{|l|}{ Cherkasy } \\
\hline \multicolumn{10}{|l|}{ Chernivtsi } \\
\hline Chernihiv & & & & & 1 & & & & \\
\hline
\end{tabular}


A simple analysis of the data in Table 1 allows us to conclude that the ratio of contracts is only $27.8 \%$. Only three-quarters of Ukraine's regions implement PPP agreements. The largest share of ups (21 out of 52) is in the field of water collection, treatment and distribution. The leader in this sphere, as well as in general on contracts quantity (11), is Mykolaiv region.

The most diverse areas of contracting are in Donetsk and Lviv regions (4 out of 9).

The practical implementation of measures to improve the energy efficiency of housing through public-private partnership mechanisms is possible through the creation of associations of co-owners of apartment buildings (condominiums). They can independently determine and implement the necessary measures to improve living conditions with their own, attracted from the state or local budget, as well as from other sources of material and financial resources. No other organizational and legal form allows them to do this, because condominiums have the opportunity to accumulate and then use the money in the repair and reserve endowments. It is these foundations that make it possible to carry out the necessary activities, enter into agreements with energy service companies (ESCOs), apply for a grant or participate in co-financing.

Forecast data on prices and tariffs indicate the prospect of their further growth, especially for gas. The energy component of the gross product of Ukraine is 2-3 times higher than that of developed countries. Payments for energy resources in the utility sector reach unaffordable limits for the population and budgets of all levels. In the context of the above, the most acceptable solution that will improve the situation in the field of energy consumption is to involve a service company (ESCO), based on an energy service contract (ESC). The main advantage of the proposed concept is to save the customer's money, as the implementation of energy-saving measures is carried out by the ESCO itself.

Given this, it becomes clear why the practice of implementing energysaving projects abroad through the creation of specialized energy service companies has become widespread. ESCOs can offer a range of services, including management services, at all stages of an energy efficiency project, from energy efficiency analysis and project development to equipment monitoring

The energy service company operates on the terms of an energy service contract concluded with the consumer, according to which the energy service company implements energy-efficient projects at its own expense (European Commission, 2013).

The subject of the energy service contract is the implementation by the executor of actions aimed at energy conservation and energy efficiency of the use of energy resources by the customer. Tasks that are solved in the process of implementation of energy service contracts: obtaining the program-target indicators of energy savings defined in the agreement during their production, transmission and consumption; achieving a certain level of comfort with optimal energy consumption. 
Tables 2 and 3 provide an overview of existing contracts that can be used to implement energy efficiency projects (Sorrell, 2007; OECD, 2015; FIATU, 2015).

Table 2

\section{Typical energy service contracts. The source of funding is the Customer}

\begin{tabular}{|c|c|c|}
\hline No. & $\begin{array}{l}\text { Type of energy } \\
\text { service contract }\end{array}$ & Features of the contract \\
\hline 1. & $\begin{array}{l}\text { Fixed payment } \\
\text { service contract }\end{array}$ & $\begin{array}{l}\text { - one of the simplest types of contract, in which the } \\
\text { customer and ESCO agree on a fixed price for the } \\
\text { development and implementation of an energy-saving } \\
\text { project; } \\
\text { - payment is made after the contract, subject to the } \\
\text { achieved level of savings; } \\
\text { - for this type of contract, special attention is paid to design } \\
\text { and implement documentation; } \\
\text { - the customer takes part during the inspection of } \\
\text { installation works. }\end{array}$ \\
\hline 2. & $\begin{array}{l}\text { The contract for } \\
\text { the provision of } \\
\text { services with } \\
\text { payment for the } \\
\text { results achieved }\end{array}$ & $\begin{array}{l}\text { - payment for the services provided is made only in the } \\
\text { case of savings and from the funds released as a result of } \\
\text { savings }\end{array}$ \\
\hline 3. & $\begin{array}{l}\text { The contract for } \\
\text { the supply of } \\
\text { equipment with a } \\
\text { fixed price }\end{array}$ & $\begin{array}{l}\text { - the object of the contract is any fixed and mobile energy- } \\
\text { efficient equipment and facilities that can be classified as } \\
\text { fixed assets (for example, mini hydropower plants, energy } \\
\text { meters) }\end{array}$ \\
\hline 4. & $\begin{array}{l}\text { Energy service } \\
\text { contract } \\
\text { («Guaranteed } \\
\text { Savings») }\end{array}$ & $\begin{array}{l}\text { - methods for measuring and controlling energy efficiency } \\
\text { are clearly established; } \\
\text { - payment for services depends on the actually achieved } \\
\text { energy savings; } \\
\text { - clearly recorded: a specific indicator of energy saving, the } \\
\text { payback period of the project through storage, the terms of } \\
\text { settlements between the customer and ESCO; } \\
\text { - in the presence of a higher level of energy efficiency, } \\
\text { ESCO receives an additional bonus; } \\
\text { - in case of non-fulfilment of the undertaken obligations, } \\
\text { ESCO makes compensatory payments (reimbursement of } \\
\text { expenses); } \\
\text { - all technical and design risks are borne by ESCO. }\end{array}$ \\
\hline 5. & $\begin{array}{l}\text { The contract for } \\
\text { energy supply, } \\
\text { maintenance and } \\
\text { management of } \\
\text { energy } \\
\text { consumption }\end{array}$ & $\begin{array}{l}\text { - payment for the provision of energy supply services is } \\
\text { received during the contract period; } \\
\text { - the duration of the contract period is from } 5 \text { to } 15 \text { years; } \\
\text { - at the preparatory stage, ESCO plans and implements } \\
\text { investment measures. This is followed by the main stage of } \\
\text { the contractual relationship, which involves refinancing the } \\
\text { investment through management and energy supply, the } \\
\text { price of which is lower than the price that the contractor } \\
\text { would pay before the reconstruction. }\end{array}$ \\
\hline
\end{tabular}




\section{Typical energy service contracts, where the source of funding is the ESCO}

\begin{tabular}{|c|c|c|}
\hline & $\begin{array}{l}\text { Type of energy } \\
\text { service contract }\end{array}$ & Features of the contract \\
\hline 1. & $\begin{array}{l}\text { Equipment leasing } \\
\text { contract with a } \\
\text { fixed price and } \\
\text { payment }\end{array}$ & $\begin{array}{l}\text { - ownership of assets is preserving; } \\
\text { - the ability to generate funds and the useful life of assets with the } \\
\text { term of payment of the lease; }\end{array}$ \\
\hline 2. & $\begin{array}{l}\text { The contract for the } \\
\text { supply of } \\
\text { equipment with } \\
\text { payment in } \\
\text { instalments }\end{array}$ & $\begin{array}{l}\text { - financial leasing propose to be widely introduced in the case of } \\
\text { lease of energy-efficient equipment and facilities, the dismantling } \\
\text { of which complicates its further (re)use by the lessor or is an } \\
\text { integral part of the technological or production processes of the } \\
\text { lessee; } \\
\text { - operating leasing provides for payment for the use of the } \\
\text { property at a fixed rate, as a result, there is an incentive to } \\
\text { efficiently operate the property and reduce operating costs. } \\
\text { Only fixed assets of the utility company can be objects for } \\
\text { leasing. }\end{array}$ \\
\hline 3. & $\begin{array}{l}\text { Energy service } \\
\text { contract for project } \\
\text { implementation } \\
\text { with income } \\
\text { distribution after } \\
\text { payment («First } \\
\text { Out») }\end{array}$ & $\begin{array}{l}\text { - until the full payback period and the projected level of } \\
\text { profitability of the energy service company, } 100 \% \text { of the revenues } \\
\text { received from the implementation of the energy efficiency project } \\
\text { remain in the ESCO; } \\
\text { - the size of the initial investment and the payback period is } \\
\text { clearly regulated; } \\
\text { - the duration of the contract directly depends on the achieved } \\
\text { level of energy savings, the higher the savings, the shorter the } \\
\text { term of the contract. }\end{array}$ \\
\hline 4. & $\begin{array}{l}\text { Energy service } \\
\text { contract with } \\
\text { income distribution } \\
\text { («Shared Savings») } \\
\end{array}$ & $\begin{array}{l}\text { - all costs associated with the development and implementation of } \\
\text { the project are covered during the contract; } \\
\text { - the distribution of revenues from energy savings carries out } \\
\text { between the customer - the end-user and ESCO. In percentage } \\
\text { terms, the customer's share is approximately } 20 \% \text { and can revise } \\
\text { after the payback of the project. The stock of ESCO includes } \\
\text { reimbursement of initial investments and fees for services } \\
\text { provided; } \\
\text { - technical and credit risks are assuming by ESCO; } \\
\text { - ESCOs must have sufficient financial capacity to borrow and } \\
\text { use debt in a balanced way, or the banking sector must be } \\
\text { developing to acquire ESCO debt through forfeiting (for example, } \\
\text { Korea, USA, Czech Republic). }\end{array}$ \\
\hline 5. & $\begin{array}{l}\text { The contract for the } \\
\text { supply of energy } \\
\text { resources and } \\
\text { energy } \\
\text { management } \\
\text { («Chauffage») }\end{array}$ & $\begin{array}{l}\text { - this type of contract is common in the countries of the European } \\
\text { Union (primarily - France, hence the name of the contract } \\
\text { «Chauffage»); } \\
\text { - the energy service provider is the energy service provider; } \\
\text { - a fixed price installing for energy resources, which is valid } \\
\text { during the contract period (from } 10 \text { to } 30 \text { years); } \\
\text { - the owner of energy-saving equipment is ESCO. }\end{array}$ \\
\hline
\end{tabular}


ESC participants are:

1. Initiator is a body of public or executive power, which has the right to distribute budget allocations (in the case of energy savings and energy efficiency in the budget sphere).

2. Customer is an enterprise or budget organization that orders a certain quality of service (comfortable temperature and humidity, the ability to use cold water, electricity, etc.), and not a certain amount of a resource.

3 . Contractor is an organization that provides energy services.

4. Investor is a bank that offers the Contractor with facilities to provide additional funds.

5. Consumer can be groups of people who use the improvements achieved in the performance of their direct duties (in educational institutions - staff and students), in medical institutions - staff and patients, in preschools - staff and children, etc.).

6. Expert is an independent organization that acts as an observer for strict compliance by all parties with the terms of the contract.

The conclusion of an energy service contract allows to reduce not only energy consumption but also operating costs. Also, it is possible to reduce staff costs and maintenance of the building.

\section{Conclusions}

There is the timely issue of developing a methodological framework that will ensure the use of mechanisms for energy service contracts within the public-private partnership at the budget level, namely: methods of measuring and verifying energy efficiency; a standardized form of reporting on the achievement of the planned amount of energy savings; methodological base with a formalized process and documentary justification for evaluating the effectiveness of projects, etc. Creation of a comprehensive methodological base, introduction of new quality standards and application of some accompanying measures will contribute to the formation of an appropriate environment for the prosperity of energy service business in Ukraine, development of the public-private partnership, professional growth and implementation of specialists in energy saving and energy efficiency, emergence of a stable interest in the conclusion and implementation of the ESCO.

It is expedient to use the mechanisms of public-private partnership management in the process of creating effective functioning and management of the development of territorial communities. The PPP approach should be used both as a tool for implementing projects and programs and as a basis for long-term cooperation between the state, private business and consumers.

One of the directions for public-private partnership is the management of apartment buildings and providing their residents with quality housing and communal services. The primary forms of such management are privatization; contract for works; enterprise management contracts (trust management); rent; concession. 
Given the peculiarities and differences of the regions of the state, for stimulating the development of associations in different parts of the country requires the implementation of the long-declared strategy of decentralization of power and increase the effectiveness of local governments. Self-organized initiative groups must independently determine the strategy for the development and improvement of both the property they own and the territory, in which the property is locating.

For overcoming the country's energy poverty, which is to some extent due to the irrational use of energy resources in society, it is necessary to implement a set of measures aimed at ensuring energy efficiency in the housing sector of Ukraine. There is also a need for state regulation of energysaving processes and purposeful state policy.

The experience of developed countries shows the effectiveness of publicprivate partnerships as a mechanism for energy efficiency in the housing sector. Prospects for the development of public-private partnership in Ukraine are possible only if the legal regulation of condominiums and the promotion of such associations motivated by advantages in the provision of housing and communal and management services, benefits from public authorities and local governments.

The PPP will be capable only if agreements between the state and private business and the consumer - residents of the amalgamated territorial community will reach. The result of the contract (mediation) is optimal in accordance with Pareto when the fee is offering by the buyer (consumer), and the seller (government and private business) agrees to its price, provided that the interests of the local community dominate in such agreements.

\section{References:}

1. Delmon, J. (2009). Private Sector Investment in Infrastructure: Project Finance, PPP Projects and Risk. The World Bank \& Kluwer Law International

2. European Commission (2013) ESCO Market Report for Non-European Countries. Retrieved from: https://publications.jrc.ec.europa.eu/repository/bitstream/JRC92730/ld-na26989-en-c\%20(print).pdf

3. FIATU (2015) Prezentacija biznes-modelej energhoservisnogho kontraktynghu. [Presentation of business models of energy service contracting]. Retrieved from: http://www.korosten-rada.gov.ua/images/economika/energy_management/__.pdf

4. Grimsey, D. \& Lewis, M. (Eds.). (2005). The Economics of Public Private Partnerships. Cheltenham: Edward Elgar Publishing Ltd.

5. Hansen, S.J., Bertoldi P., Langlois P. (2009). ESCOs Around the World: Lessons Learned in 49 Countries. Lilburn: The Fairmont Press.

6. Hart, O. (2003). Incomplete Contracts and Public Ownership: Remarks and Application to Public-Private Partnerships. The Economic Journal, 113 (486), pp. 69-76, Retrieved from: https://papers.ssrn.com/sol3/papers.cfm?abstract_id=388760

7. Hodge, G. (2010). Reviewing Public-Private Partnerships. Some Thoughts on Evaluation. In Hodge, G., Greve, C. \& Boardman, A. (Eds.) International Handbook on Public-Private Partnerships (pp. 81-112). Cheltenham: Edward Elgar. DOI: $10.4337 / 9781849804691.00012$

8. Maksymenko, O.L. (Ed.). (2015). Formuvannja jedynykh kryterijiv ocinky Upravljajuchykh kompanij $u$ sferi zhytlovo-komunaljnykh poslugh: kolektyvna monoghrafija [Formation of common evaluation criteria for Management Companies in 
the field of housing and communal services: a collective monograph]. Kyiv: VISTKA. Retrieved from: http://emau.kiev.ua/wp-content/uploads/2017/07/Formuvanya_kriteriiv.pdf

9. Maksymov, A. at al. (2015). Energhoefektyvnistj $v$ municypaljnomu sektori. Navchaljnyj posibnyk dlja posadovykh osib miscevogho samovrjaduvannja. [Energy efficiency in the municipal sector. Training manual for local government officials]. Kyiv: VINEJ. Retrieved from: https://enefcities.org.ua/upload/files/3energoefweb\%281\%29.pdf

10. Ministry of Economic Development, Trade and Agriculture of Ukraine (2020). Stan zdijsnennja DPP v Ukrajini. [Status of PPP implementation in Ukraine] Retrieved from: https://www.me.gov.ua/Documents/Detail?lang=uk-UA\&id=9fc90c5e-2f7b-44b28bf1-1ffb7ee1be26\&title=StanZdiisnenniaDppVUkraini

11. Nejkova, I.S. (2010). Derzhavno-pryvatne partnerstvo jak skladova investycijnogho mekhanizmu innovacijnogho rozvytku [Public-private partnership as a component of the investment mechanism of innovative development]. Naukovyj visnyk Nacionaljnogho universytetu DPS Ukrajiny (ekonomika, pravo), 1(48), 152-169.

12. Novoseltsev, A.V. \& Evtukhova, T.O. (2003) Mekhanizm ekonomichnogho stymuljuvannja energhozberezhennja na pidpryjemstvakh komunaljnoji vlasnosti [Economic incentive tool to energy conservation at municipal enterprises]. The Problems of General Energy, 1(8), 40-47.

13. OECD (2015) Pidvyshhennja konkurentospromozhnosti v Ukrajini shljakhom stvorennja stalogho zakonodavchogho pidgruntja dlja roboty energhoservisnykh kompanij [Increasing competitiveness in Ukraine by creating a sustainable legal basis for the operation of energy service companies]. Retrieved from: https://www.oecd.org/eurasia/ competitiveness-programme/eastern-partners/Framework_ESCO_Ukraine_UKR.pdf

14. Pavljuk, K. V. \& Pavljuk, S. M. (2010). Sutnistj i rolj derzhavno-pryvatnogho partnerstva $\mathrm{v}$ socialjno-ekonomichnomu rozvytku derzhavy [The essence and role of public-private partnership in the socio-economic development of the state]. Naukovi praci Kirovoghradsjkogho nacionaljnogho tekhnichnogho universytetu. Ekonomichni nauky, 17, 10-19. Retrieved from: http://nbuv.gov.ua/UJRN/Npkntu_e_2010_17_4

15. Sorrell, S. (2007). The Economics of Energy Service Contracts. Energy Policy, 35(1), 507-521. DOI: 10.1016/j.enpol.2005.12.009

16. Timofjejev, V.O. \& Chumachenko, I. V. (Eds). (2016). Informacijni tekhnologhiji ta innovaciji $v$ ekonomici, upravlinni proektamy $i$ proghramamy: monoghrafija. [Information technologies and innovations in economics, project and program management: monograph.]. Kharkiv: KhNURE.

17. Zakonodavstvo Ukrainy. (2010, July 1). Zakon Ukrajiny pro derzhavno-pryvatne partnerstvo \# 2404-VI [Law of Ukraine on Public-Private Partnership No. 2404-VI]. Retrieved from: https://zakon.rada.gov.ua/laws/show/2404-17\#Text

18. Zapatrina, I. V. (2010). Publichno-pryvatne partnerstvo v Ukrajini: perspektyvy zastosuvannja dlja realizaciji infrastrukturnykh proektiv i nadannja publichnykh poslugh [Public-private partnership in Ukraine: prospects of application for the implementation of infrastructure projects and the provision of public services]. Ekonomika ì prognozuvannâ, 4, 62-86. Retrieved from: http://eip.org.ua/docs/EP_10_4_62_uk.pdf

19. Zapatrina, I. V. (2011). Rozvytok derzhavnoji pidtrymky publichno-pryvatnogho partnerstva $\mathrm{v}$ Ukrajini [Development of state support for public-private partnership in Ukraine] Ekonomika i prognozuvannâ, 3, 9-24. Retrieved from: http://eip.org.ua/docs/ EP_11_3_09_uk.pdf 